\title{
Study of the Presence of Pesticides in Treated Urban Wastewaters
}

\author{
María P. Ormad, Natividad Miguel, Rosa Mosteo, \\ Jorge Rodríguez and José L. Ovelleiro \\ Department of Chemical Engineering and Environmental Technologies, \\ Spain
}

\section{Introduction}

The increase of the industrial activity and the consequent economic and social development have produced, at least until some years ago, a growth of big cities which leads and complicates the supply of one of the most important elements to the life, "water". Nowadays, faced with the growing water demand and the hydric resources shortage, the reuse of treated water is considered as a possible solution in order to increase existing resources. However, all effluents can't be reused since environmental minimum flows have to be guaranteed downstream of the dumping (Ormad, 2011).

The water reuse is the application, before its return to the public water resources and the terrestrial maritime one to a new exclusive use of waters that, having been used by who derived them, they have been subjected to a process or processes of treatment established in the corresponding authorization of dumping and to the necessary in order to get the quality required in function of uses to which it goes to be destined. As well, reuse waters are treated wastewaters that have been subjected to an additional or complementary process which is capable to adapt its quality to the destined use. All this is carried out in reclamation plants, group of installations where treated wastewaters are subjected to additional treatments which can be needed in order to adapt the water quality to the destined use (Royal Decree 1620/2007).

Waters which go to be reclaimed, it is, treated wastewaters, are waters that must obey the specifications of Directive 91/271/EEC (Directive 91/271/EEC). However, in these waters can exist some substances which can be pollutants. In general, the composition of these waters mainly depends on two factors: the industrial contribution to the urban dumping and the type of water treatment in the wastewater treatment plant (WWTP). In spite of this, in general, these waters are characterized by:

- The presence of a great variety of pathogenic germs

- The presence of organic matter, with a Biologycal Oxygen Demand 5-day $\left(\mathrm{BOD}_{5}\right)$ up to $25 \mathrm{mg} \mathrm{L}^{-1}$ and a Chemical Oxygen Demand (COD) up to $125 \mathrm{mg} \mathrm{L}^{-1}$ (according to the current legislation). In this generic group, there are two types of organic matter:

- Non Hazardous Organic Matter: This organic matter is mayoritary composed by compunds which haven't degraded in the WWTP. This is because they are refractary compounds or the achieved yields aren't of $100 \%$; they are organic substances non toxic like carboxilic acids, esters, proteins, carbon hydrates, aminoacids, polihydroxilated alcohols, etc. 
- Hazardous Organic Matter: persistent substances which haven't been removed in the WWTP. If these substances are present with low concentrations can derive in an environmental and health problem. They are pharmaceutical products, clean and care personal products, pesticides and plasticizers. Some of these compounds have characteristics toxic, cancinogenic, mutagenic, teratogenic, bioaccumulative or endocrin disruptors, and they are part of a big group of organic compounds, called Emerging Pollutants, which are received great attention in the last years (Hernando et al., 2006). All are hazardous compounds such as Directives 80/68/EEC, 2000/60/EC and 2006/11/EC establish (Directives 80/68/EEC, 2000/60/EC, 2006/11/EC).

- $\quad$ The presence of suspended solids, with a concentration up to $60 \mathrm{mg} \mathrm{L}^{-1}$.

- High turbidiy

- The presence of inorganic pollutants, such as chlorides, nytrogen and phosphorus (with different concentrations depending on the plant of which come from, with or without nutrients removal) and, in some cases, heavy metals which haven't been removed in the WWTP and which concentration mainly depends on the industrial part that the urban dumping has.

Effluents of WWTPs can be reused to urban, agricultural, industrial, recreational and environmental uses. It is expected an urban use as irrigation of private gardens, emptying of healthy apparatus, irrigation of urban green places such as parks, sport fields and similar, cleaning of streets, systems against fires and industrial cleaning of vehicles. As agricultural use, it is expected the irrigation of cultivation which is consumed in fresh form or has an industrial treatment to its consume, irrigation of pasture to animal consumption, aquaculture, irrigation of woody cultivation, cultivation of ornamental flowers, nurseries, greenhouses and irrigation of industrial and no alimentary cultivation. It is considered the reuse as industrial use as cleaning and process water, in cooling towers and evaporative condensers. It is considered recreational use the irrigation of golf courses, ponds, water masses and ornamental circulated flows in which the public access to water is blocked. Finally, to environmental use it is expected the use of water to fill aquifers by percolation or direct injection, irrigation of woods and other green places which aren't accessible to people, silviculture, maintenance of wetlands, minimum flows and similar.

To carry out all of these uses, indicated in the Spanish current legislation about reclaimed water (Royal Decree 1620/2007) it is necessary to carry out a treatment which gets the minimum criteria of quality demanded in relation with several parameters. In general, this treatment has to remove the suspension matter, the turbidity, the hazardous substances and to disinfect the water, as a minimum (Metcalf and Eddy, 2002).

On the other hand, depend on the use of reclaimed water, apart from considering the quality criteria indicated in the Royal Decree 1620/2007, other criteria included in specific fields have to be considered; for example, Directive 2006/118/EC has to be considered, directive related to the protection of groundwaters against the pollution and deterioration when the reclaimed water is destined to environmental use (Directive 2006/118/EC). This norm includes Environmental Quality Standards (EQSs) related to nitrates, salinity, metals, trichloroethylene, tetrachloroetylene and other hazardous substances such as pesticides. Also the Directive 80/68/EEC establishes that it is necessary to impede the dumping of hazardous substance of the List I and to limit the dumping of the hazardous substances of the List II, lists in which a lot of pesticides are founded, in order to guarantee an effective protection of groundwaters. In the same way, the Spanish Royal Decree 60/2011 (Royal Decree 60/2011) by which quality objectives to some pollutants are fixed and the Reglament of Public Waters is modified, establishes EQSs to Preferential Hazardous Substances of the List II. Likewise, in the 
application of the Directive 2000/60/EC the Decision 2455/2001 establishes the relation of Priority Hazardous Substances of the European Union which dumping to surface and groundwaters has to be limited. In this relation are included a lot of pesticides too.

The aim of this work is the characterization of urban treated wastewaters from different treatments with the purpose of knowing the presence of pesticides in these waters and if these waters can be reused or need an additional treatment for this. All studied WWTPs are located in the Ebro river Basin (Spain). Moreover, a bibliographic revision related to the pesticides mainly detected in this type of waters has been carried out.

This work has been carried out in collaboration with "Navarra Infraestucturas Locales S.A." (NILSA) by the Research Project "Regeneración de aguas depuradas mediante procesos de oxidación avanzada (CTM2008-01876/TECNO)".

\section{Description of the selected WWTPs}

The five selected WWTPs in this study are located in the "Comunidad Foral de Navarra" (Spain). Next a detailed description of the characteristics and process carried out in each WWTP are described.

\subsection{WWTP-A}

The description of this WWTP is as follow:

- Water origin: urban and industrial coming from companies of food and cans handling

- $\quad$ Equivalent inhabitants: 15869

- $\quad$ Designed flow: $2860 \mathrm{~m}^{3}$ day-1 $^{-1}$

- $\quad$ Treated flow: $2129 \mathrm{~m}^{3}$ day ${ }^{-1}$

- $\quad$ Designed organic load: $3000 \mathrm{~kg} \mathrm{BOD}_{5}$ day ${ }^{-1}$

- $\quad$ Treated organic load: $2820 \mathrm{~kg} \mathrm{BOD}_{5}$ day ${ }^{-1}$

Stages of the treatment in this WWTP are shown in the figure 1. Water arrives by sewers to the WWTP. After homogenizing water in a pond, the treatment consists of the separation of big and medium solids by sieves which act as desander/degreaser too. After water passes to the primary decanter during a retention time of 3-6 hours. Decanted muds are retired to treat them. The effluent of the decanter goes to biological reactor consisting of a percolator filter with plastic layer. After the secondary decantation, water goes to a lagoon system consisting of 4 lagoons put in series. Lagoons are 2.5 meters deep. Rests of organic matter are removed and the removal of pathogen germs happens too due to the effect of the solar radiation. The residence time of water in lagoons is about 25 days.

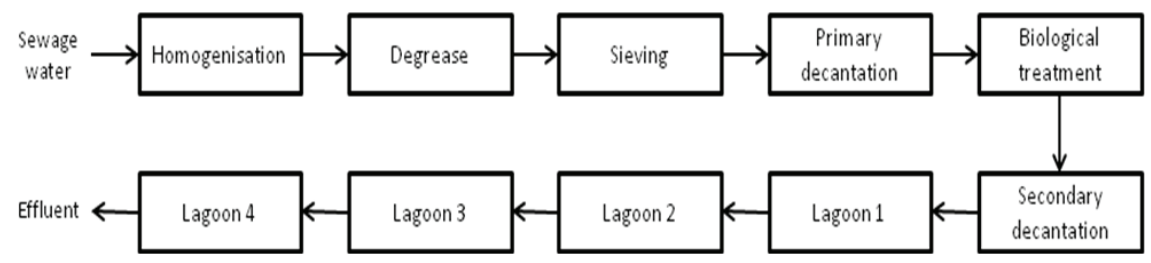

Fig. 1. Diagram of stages in the WWTP-A

\subsection{WWTP-B}

The description of this WWTP is as follow:

- Water origin: urban and industrial coming from chemical, textile and mechanical industries 
- $\quad$ Equivalent inhabitants: 46237

- $\quad$ Designed flow: $20416 \mathrm{~m}^{3}$ day-1 $^{-1}$

- $\quad$ Treated flow: $16734 \mathrm{~m}^{3}$ day ${ }^{-1}$

- $\quad$ Designed organic load: $6876 \mathrm{~kg}^{\mathrm{BOD}} \mathrm{D}_{5}$ day ${ }^{-1}$

- Treated organic load: $5522 \mathrm{~kg} \mathrm{BOD}_{5}$ day ${ }^{-1}$

Stages of the treatment in this WWTP are shown in the figure 2. Water arrives by a sewer system to the WWTP and it is subjected to a pretreatment consisting of the separations of thick solids by deflector sheets or sieves. After the degrease and desanding are carried out. This consisting of the extraction of mineral particles and the removal of greases, oils and floating material. Next obtained water goes to a primary decanter which purpose is decrease the suspension matter of the water. After this removal of matter, the biological treatment is carried out. The biological treatment is produced by bacterium layers. Finally, the biological mud is separated from water in the secondary decantation.

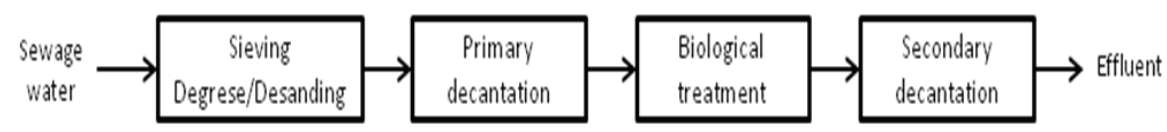

Fig. 2. Diagram of stages in the WWTP-B

\subsection{WWTP-C}

The description of this WWTP is as follow:

- Water origin: urban and industrial coming from carpentry industries, mechanical garages, vegetable preserved food industries and wineries

- Equivalent inhabitants: 3453

- $\quad$ Designed flow: $308 \mathrm{~m}^{3}$ day $^{-1}$

- $\quad$ Treated flow: $361 \mathrm{~m}^{3}$ day ${ }^{-1}$

- $\quad$ Designed organic load: $110 \mathrm{~kg} \mathrm{BOD}_{5}$ day ${ }^{-1}$

- $\quad$ Treated organic load: $149 \mathrm{~kg} \mathrm{BOD}_{5}$ day ${ }^{-1}$

Stages of the treatment in this WWTP are shown in the figure 3. The sewage water arrives to the plant pass through a sieve where big solids are removed. After, water goes to the primary decanter in order to remove the suspended matter from water. Next water goes to the biological reactor which has a bacterium layer composed by stone and plastic where the organic load of water is reduced considerably. Aftherthat, the reduction of suspended matter is increased in a secondary decanter. After these processes, there is a tertiary treatment consisting of 4 lagoons. The residence time of water in lagoons is 5-6 days. The function of these lagoons is degrade the organic matter or the water and complete the disinfection by the effect of the solar radiation.

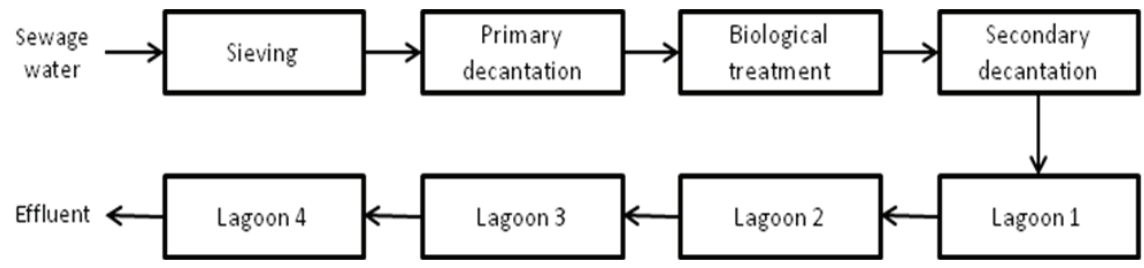

Fig. 3. Diagram of stages in the WWTP-C 


\subsection{WWTP-D}

The description of this WWTP is as follow:

- Water origin: urban and agricultural

- Equivalent inhabitants: 4376

- $\quad$ Designed flow: $1800 \mathrm{~m}^{3}$ day $^{-1}$

- $\quad$ Treated flow: $983 \mathrm{~m}^{3}$ day ${ }^{-1}$

- $\quad$ Designed organic load: $336 \mathrm{~kg} \mathrm{BOD}_{5}$ day ${ }^{-1}$

- $\quad$ Treated organic load: $195 \mathrm{~kg} \mathrm{BOD}_{5}$ day ${ }^{-1}$

Stages of the treatment in this WWTP are shown in the figure 4 . Water which arrives to the WWTP is pumped to the sieve. The sieve operates as desander/degreaser too. After water goes to an anoxic biological reactor with agitation by which nitrogen and phosphorous is partially removed. Next, water goes to a decanter.

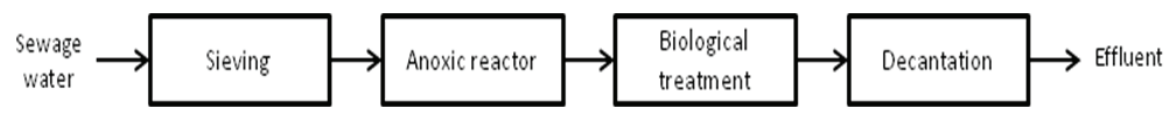

Fig. 4. Diagram of stages in the WWTP-D

\subsection{WWTP-E}

The description of this WWTP is as follow:

- Water origin: urban and industrial coming from winery industries

- Equivalent inhabitants: 27154

- Designed flow: $4633 \mathrm{~m}^{3}$ day-1 $^{-1}$

- $\quad$ Treated flow: $3400 \mathrm{~m}^{3}$ day ${ }^{-1}$

- Designed organic load: $1357 \mathrm{~kg} \mathrm{BOD}_{5}$ day ${ }^{-1}$

- $\quad$ Treated organic load: $958 \mathrm{~kg} \mathrm{BOD}_{5}$ day ${ }^{-1}$

Stages of the treatment in this WWTP are shown in the figure 5. Once sewage water arrives to the plant, it is subjected to a pretreatment. This pretreatment consists of a sieve which removes big solids and a pump that raises the water up to the degreaser/desander. Moreover, this stage has an auxiliary reactor which is used when peaks flow happens. Finally, the primary decanter removes a great part of solids. The secondary treatment consists of two biological reactors and one secondary decanter. In the first, water goes to a big lagoon in which the nitrogen is removed. In the bottom of this lagoon there are two stirrers which purpose is to avoid the decantation of solids. The residence time of water is a bit higher than in the aerobic reactor. The second part of the degradation is carried out in an aerobic reactor with two stages in series. In its interior there is a plastic layer in which the biomass is fixed.

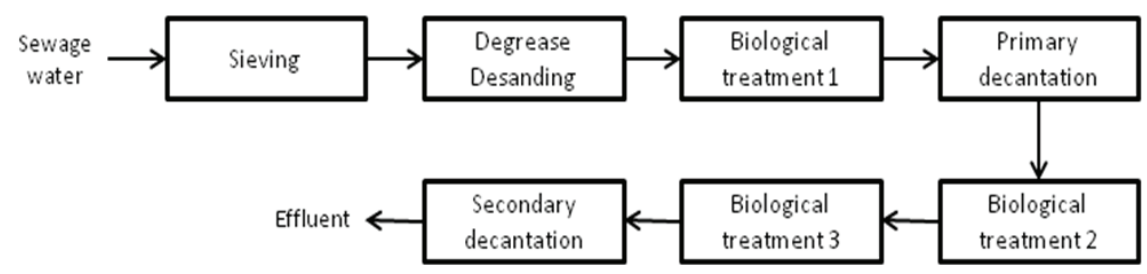

Fig. 5. Diagram of stages in the WWTP-E 


\section{Materials and methods}

\subsection{Samples}

The sampling of WWTPs effluents, waters under study in this work, was carried out in May 2009 in the outlet of each WWTP. Samples were conserved refrigerated until their analysis.

\subsection{Characterization of samples and methodology}

The characterization of samples was carried out by the analysis of physical-chemical parameters and the methodology shown in the table 1.

\begin{tabular}{|c|c|c|}
\hline Parameter & Analytic methodology & Reference \\
\hline $\mathrm{pH}$ & Standard Method 4500- $\mathrm{H}^{+} \mathrm{B}$ & Eaton et al., 2005 \\
\hline Conductivity & $\begin{array}{c}\text { Norm UNE-EN ISO } \\
7888: 1985\end{array}$ & ISO 7888:1985 \\
\hline Turbidity & Norm ISO 7027:1999 & ISO 7027:1999 \\
\hline Suspended solids concentration & Standard Method 2540 D & Eaton et al., 2005 \\
\hline Chemical Oxygen Demand & EPA Method 410.4 & EPA Method 410.4 \\
\hline Biological Oxygen Demand 5-days & Standard Method 5210 B & Eaton et al., 2005 \\
\hline
\end{tabular}

Table 1. Characterization of effluents of WWTPs

\subsection{Analysis of pesticides}

EPA method 525.5 (EPA Methods 525.2) is used in order to determine the presence of pesticides in samples. This method is based on gas chromatography and mass spectrometry with a previous solid-liquid extraction.

An Autotrace Workstation (Zymark) automatic extractor was used for the extraction. The chromatographic conditions and equipment used are shown in table 2 and the results of the methodology validation in table 3 . The results were obtained using the Xcalibur POLARIS 1.2 version program (ThermoQuest).

\begin{tabular}{|c|c|}
\hline \multicolumn{2}{|c|}{ Gas chromatographer TRACE GC 2000 (TermoFinnigan) } \\
\hline Column & DB5-MS (J\&W, $30 \mathrm{~m}, 0.25 \mathrm{~mm}, 0.25 \mu \mathrm{m})$ \\
\hline Program of temperatures & $\begin{array}{c}90^{\circ} \mathrm{C}(1 \mathrm{~min})-20^{\circ} \mathrm{C} \mathrm{min}^{-1}-180^{\circ} \mathrm{C}(1 \mathrm{~min})-2^{\circ} \mathrm{C} \mathrm{min}^{-1}- \\
240^{\circ} \mathrm{C}(1 \mathrm{~min})-20^{\circ} \mathrm{C} \mathrm{min}^{-1}-310^{\circ} \mathrm{C}(10 \mathrm{~min})\end{array}$ \\
\hline Injector temperature & $250^{\circ} \mathrm{C}$ \\
\hline Injection volume & $1 \mu \mathrm{L}$, splitless $0.8 \mathrm{~min}$ \\
\hline Carrier gas & He (N55), $1 \mathrm{~mL} \mathrm{~min} \mathrm{~m}^{-1}$ \\
\hline \multicolumn{2}{|c|}{ Mass spectrometer POLARIS (ThermoFinnigan) } \\
\hline Ionization energy & $70 \mathrm{eV}$ \\
\hline Acquisition mode & Full scan \\
\hline Mass interval & $50-450 \mathrm{amu}$ \\
\hline Screen speed & 1 scan s$^{-1}$ \\
\hline Acquisition time & $32.5 \mathrm{~min}$ \\
\hline
\end{tabular}

Table 2. Conditions of pesticides analysis 


\begin{tabular}{|c|c|c|c|c|c|c|}
\hline \multirow[b]{2}{*}{ Pesticide } & \multicolumn{2}{|c|}{$\begin{array}{c}\text { Quantification limit } \\
\left(\mu \mathrm{g} \mathrm{L}^{-1}\right)\end{array}$} & \multirow{2}{*}{$\begin{array}{c}\text { Calibration } \\
\text { interval } \\
\left(\mu g \mathrm{~L}^{-1}\right)\end{array}$} & \multirow{2}{*}{$\begin{array}{c}\text { Validity } \\
\text { interval } \\
\left(\mu g L^{-1}\right)\end{array}$} & \multicolumn{2}{|c|}{$\begin{array}{c}\text { Recovery interval } \\
(\%)\end{array}$} \\
\hline & \begin{tabular}{|c|}
$\begin{array}{c}\text { Instrumental } \\
\text { step }\end{array}$ \\
\end{tabular} & $\begin{array}{c}\text { Full } \\
\text { method }\end{array}$ & & & \begin{tabular}{|c|}
$\begin{array}{c}\text { Instrumental } \\
\text { step }\end{array}$ \\
\end{tabular} & $\begin{array}{c}\text { Full } \\
\text { method }\end{array}$ \\
\hline Isoproturon & 20 & 0.030 & $20-500$ & $0.030-300$ & $75-130$ & $63-110$ \\
\hline Diuron & 20 & 0.030 & $20-500$ & $0.030-300$ & $82-128$ & $70-123$ \\
\hline 3.4-Dichloroaniline & 20 & 0.030 & $20-500$ & $0.030-300$ & $88-130$ & $47-106$ \\
\hline 4-Isopropylaniline & 20 & 0.030 & $20-500$ & $0.030-300$ & $80-130$ & $60-125$ \\
\hline Desethylatrazine & 20 & 0.030 & $20-500$ & $0.030-300$ & $76-130$ & $80-129$ \\
\hline Trifluralin & 20 & 0.015 & $20-500$ & $0.030-300$ & $70-130$ & \begin{tabular}{|l|}
$70-127$ \\
\end{tabular} \\
\hline Dimethoate & 20 & 0.030 & $50-500$ & $0.030-300$ & $66-124$ & $54-137$ \\
\hline Simazine & 50 & 0.030 & $20-500$ & $0.030-600$ & $75-135$ & 64-127 \\
\hline Prometon & 20 & 0.030 & $20-500$ & $0.030-300$ & $76-124$ & $0-125$ \\
\hline Atrazine & 200 & 0.100 & $200-5000$ & $0.100-300$ & $78-130$ & $75-127$ \\
\hline Propazine & 20 & 0.015 & $20-500$ & $0.015-300$ & $86-130$ & $73-127$ \\
\hline Terbuthylazine & 20 & 0.015 & $20-500$ & $0.015-300$ & $79-130$ & $83-128$ \\
\hline Parathion methyl & 50 & 0.030 & $50-500$ & $0.030-300$ & $78-139$ & $72-130$ \\
\hline Parathion ethyl & 20 & 0.030 & $20-500$ & $0.030-300$ & $74-122$ & $64-128$ \\
\hline Alachlor & 20 & 0.015 & $20-500$ & $0.015-300$ & $75-125$ & $70-124$ \\
\hline Ametryn & 20 & 0.030 & $20-500$ & $0.030-300$ & $78-130$ & $0-116$ \\
\hline Prometryn & 20 & 0.030 & $20-500$ & $0.030-300$ & $80-120$ & $17-116$ \\
\hline Terbutryn & 20 & 0.030 & $20-500$ & $0.030-300$ & $80-120$ & $13-114$ \\
\hline Chlorpyrifos & 20 & 0.015 & $20-500$ & $0.015-300$ & $75-120$ & \begin{tabular}{|l|}
$73-116$ \\
\end{tabular} \\
\hline Chlorfenvinfos & 20 & 0.015 & $20-500$ & $0.015-300$ & $76-130$ & $70-126$ \\
\hline $\mathrm{HCHs}$ & 20 & 0.015 & $20-500$ & $0.015-300$ & $84-124$ & $70-120$ \\
\hline Hexachlorobenzene & 20 & 0.030 & $20-500$ & $0.030-300$ & $70-130$ & $74-136$ \\
\hline Heptachlor & 20 & 0.015 & $20-500$ & $0.015-300$ & $75-130$ & $58-113$ \\
\hline Heptachlor epoxide A & 20 & 0.015 & $20-500$ & $0.015-300$ & $85-125$ & $62-112$ \\
\hline Heptachlor epoxide B & 20 & 0.015 & $20-500$ & $0.015-300$ & $84-130$ & $58-113$ \\
\hline Aldrin & 20 & 0.015 & $20-500$ & $0.015-300$ & $85-125$ & $64-126$ \\
\hline $\begin{array}{c}4.4^{\prime}- \\
\text { Dichlorobenzophenone }\end{array}$ & 20 & 0.015 & $20-500$ & $0.015-300$ & $75-120$ & $68-126$ \\
\hline Isodrin & 20 & 0.015 & $20-500$ & $0.015-300$ & $85-125$ & $66-120$ \\
\hline a-Endosulphan & 20 & 0.015 & $20-500$ & $0.015-300$ & $70-125$ & $70-93$ \\
\hline $\mathrm{pp}^{\prime}-\mathrm{DDE}$ & 20 & 0.015 & $20-500$ & $0.015-300$ & $89-122$ & $64-107$ \\
\hline Dieldrin & 20 & 0.015 & $20-500$ & $0.015-300$ & $70-125$ & $62-120$ \\
\hline Endrin & 20 & 0.015 & $20-500$ & $0.015-300$ & $80-125$ & $74-122$ \\
\hline $\mathrm{pp}^{\prime}-\mathrm{DDD}+\mathrm{op}^{\prime}-\mathrm{DDT}$ & 40 & 0.030 & $40-1000$ & $0.030-600$ & $79-125$ & $66-139$ \\
\hline Endosulphan-sulphate & 20 & 0.015 & $20-500$ & $0.015-300$ & $83-125$ & $73-126$ \\
\hline pp'-DDT & 20 & 0.030 & $20-500$ & $0.030-300$ & $76-130$ & $50-120$ \\
\hline Dicofol & 50 & 0.030 & $50-500$ & $0.030-300$ & $80-148$ & $63-136$ \\
\hline Methoxychlor & 20 & 0.015 & $20-500$ & $0.015-300$ & $77-126$ & $75-130$ \\
\hline Metholachlor & 20 & 0.015 & $20-500$ & $0.015-300$ & $76-115$ & \begin{tabular}{|l|}
$73-128$ \\
\end{tabular} \\
\hline Molinate & 20 & 0.015 & $20-500$ & $0.015-300$ & $91-130$ & $75-113$ \\
\hline Tetradifon & 20 & 0.015 & $20-500$ & $0.015-300$ & $85-130$ & $70-116$ \\
\hline
\end{tabular}

Table 3. Results of the methodology validation of pesticides analysis. 


\section{Results}

\subsection{Characterization of effluents of selected WWTPs}

As it has been mentioned previously, the characterization of WWTPs effluents is carried out by several physical-chemical parameters, among them, turbidity and suspended solids concentration, which are parameters whose maximum admissible values are indicated in the Spanish legislation related to water reclamation (Royal Decree 1620/2007). Characterization results of WWTPs effluents are shown in the table 4.

\begin{tabular}{|c|c|c|c|c|c|}
\hline Parameter & $\begin{array}{c}\text { WWTP- } \\
\text { A }\end{array}$ & $\begin{array}{c}\text { WWTP- } \\
\text { B }\end{array}$ & $\begin{array}{c}\text { WWTP- } \\
\text { C }\end{array}$ & $\begin{array}{c}\text { WWTP- } \\
\text { D }\end{array}$ & $\begin{array}{c}\text { WWTP- } \\
\text { E }\end{array}$ \\
\hline $\mathrm{pH}\left(\right.$ temperature in $\left.{ }^{\circ} \mathrm{C}\right)$ & $7.6(14.7)$ & $7.9(15.8)$ & $7.4(11.1)$ & $7.2(18.6)$ & $7.3(13.5)$ \\
\hline Conductivity $\left(\mu \mathrm{Sm}^{-1}\right)$ & 3220 & 1867 & 1086 & 2950 & 832 \\
\hline Turbidity (NTU) & 34.0 & 12.3 & 1.7 & 34.7 & 5.4 \\
\hline $\begin{array}{c}\text { Suspended solids } \\
\text { concentration (mg L-1) }\end{array}$ & 56 & 8 & 4 & 32 & 20 \\
\hline $\begin{array}{c}\text { Chemical Oxygen Demand } \\
\left(\mathrm{mg} \mathrm{L}^{-1}\right)\end{array}$ & 84 & 60 & 77 & 62 & 50 \\
\hline $\begin{array}{c}\text { Oxygen Biological Demand } \\
\text { 5-days (mg L-1) }\end{array}$ & 16.4 & 17.5 & 15.3 & 15.5 & 12.5 \\
\hline
\end{tabular}

Table 4. Results of the characterization of studied effluents

As well as this characterization, a bibliographic study was carried out. This study was done in order to confirm that the results of the selected WWTPs obtained are between typical values regarding characteristics of WWTPs effluents. In accordance with this study, habitual values of analyzed parameters in WWTPs effluents are shown in the table 5 (Imai et al., 2002; Mendoça et al., 2007; Hassanli et al., 2008; Kalavrouziotis et al., 2009; Santos et al., 2009).

In accordance with the obtained results it can be observed that the characterization values of the selected effluents are within usual intervals to effluents of WWTPs.

\begin{tabular}{|c|c|}
\hline Parameter & Interval \\
\hline $\mathrm{pH}$ & $7-8$ \\
\hline Conductivity $\left(\mu \mathrm{S} \mathrm{cm}{ }^{-1}\right)$ & $70-3200$ \\
\hline Turbidity $(\mathrm{NTU})$ & $3-52$ \\
\hline Suspended solids concentration $\left(\mathrm{mg} \mathrm{L}^{-1}\right)$ & $4-92$ \\
\hline Chemical Oxygen Demand $\left(\mathrm{mg} \mathrm{L}^{-1}\right)$ & $19-98$ \\
\hline Oxygen Biological Demand 5-days $\left(\mathrm{mg} \mathrm{L}^{-1}\right)$ & $5-31$ \\
\hline
\end{tabular}

Table 5. Usual values of physical-chemical parameters in WWTPs effluents according to other references

\subsection{Presence of pesticides in effluents of WWTPs}

In general, in effluents of selected WWTPs exists the presence of several pesticides. Among all analyzed pesticides, 10 different pesticides have been detected: chlorfenvinfos, chlorpyrifos, dimethoate, isoproturon, prometon, metholachlor, 3,4-dichloroaniline, terbutryn, terbuthylazine and simazine. Chemical structures of detected pesticides in studied effluents are shown in the figure 6. 


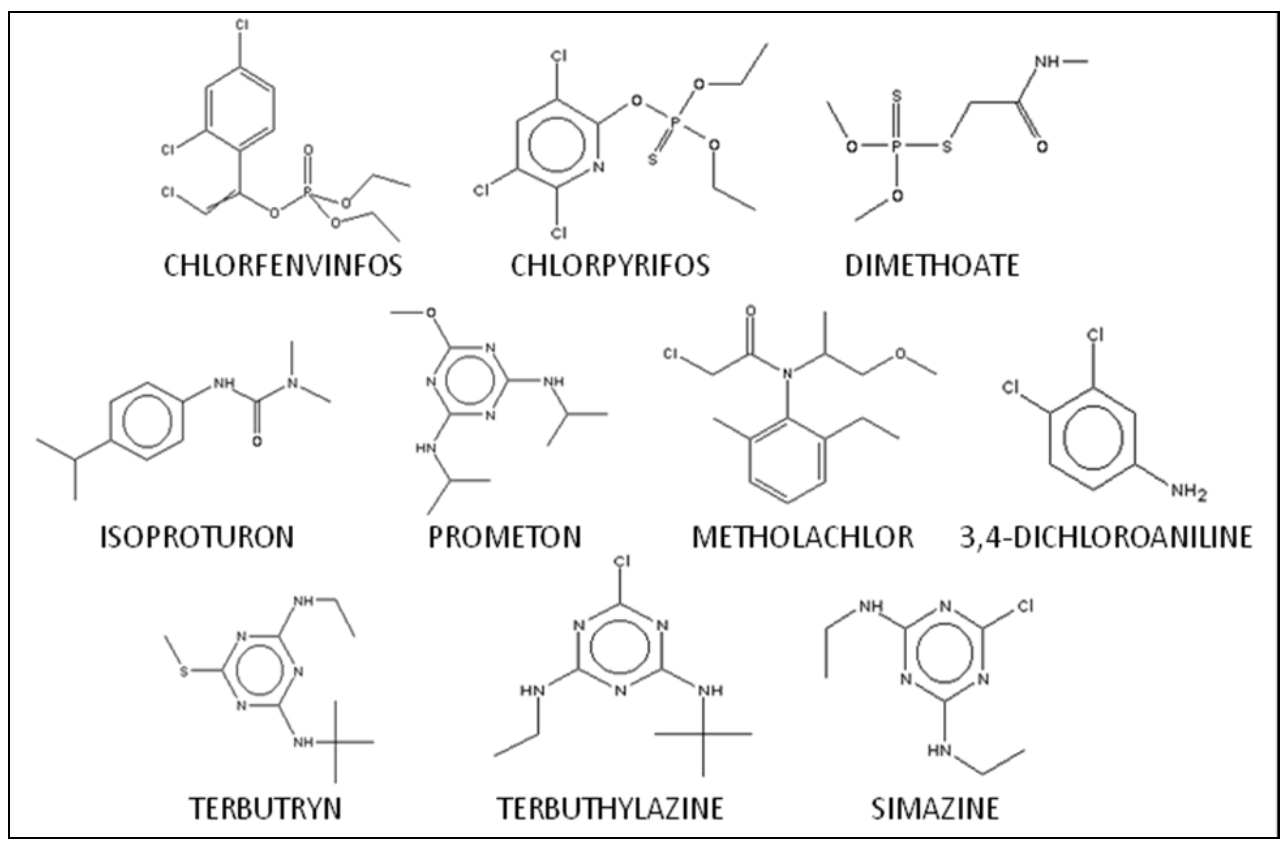

Fig. 6. Chemical structures of detected pesticides in effluents of studied WWTPs

Detected pesticides belong to different groups.

In the first place, organic-phosphorous pesticides such as chlorfenvinfos, chlopyrifos and dimethoate are detected. These pesticides are mainly used as insecticides. Chlorpyrifos and dimethoate are very toxic and chlorfenvinfos is extremely toxic. The main effects in the health caused by these pesticides are irritation of eyes and skin and if the exposition to these pesticides is long-term they can affect to nervous, respiratory and immunological systems.

Pesticides derived of urea such as isoproturon and diuron are detected too. These pesticides are mainly used as herbicides and they are moderately toxic compounds. They can cause irritation of skin, eyes and respiratory system, in addition to blood alterations in the case of extend expositions.

Some of detected pesticides belong to triazines group; they are terbutryn, terbuthylazine and simazine. These pesticides are mainly used as herbicides and they are moderately toxic substances. With respect to effects on health, the can cause irritation in eyes and skin and moreover, affections in liver, kidney, nervous and circulatory systems in the case of longterm contact.

Finally, the rest of detected pesticides are metholachlor and 3,4-dichloroaniline. Metholachlor belongs to anilide group, it is a moderately toxic substance and used as herbicide. It can cause irritation in eyes and in the case of long-term exposition it can provoke liver and blood conditions. 3.4-dichloroaniline is used as herbicide and it is a moderately toxic pesticide. It can cause dermatitis and damages in liver and kidney after long-term expositions.

Some of the pesticides detected in the studied effluents, such as chlorpyrifos, chlorfenvinfos, isoproturon and simazine were detected in other effluents of WWTPs such as it is shown in 
other research works. As well as these pesticides, in these studies other pesticides were detected: $\alpha$-endosulphan, hexachlorociclohexanes $(\alpha, \beta, \chi, \delta)$, atrazine, diuron, hexachlorobenzene, endrin, dieldrin, heptachlor, heptachlor epoxide B, $\mathrm{pp}^{\prime}$-DDD and $\mathrm{pp}^{\prime}$ DDE (Kastsoyiannis and Samara, 2004; Muñoz et al., 2008). Chemical structures of theses pesticides are shown in the figure 7.

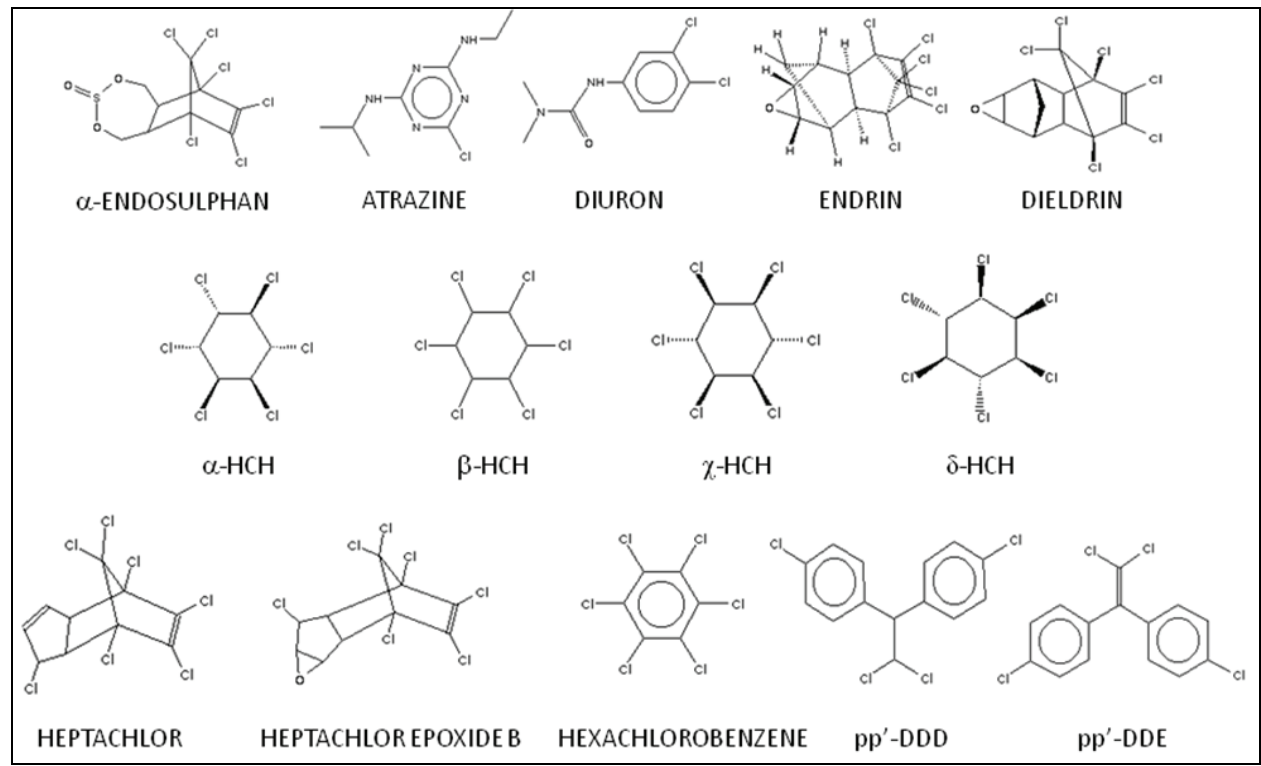

Fig. 7. Chemical structures of pesticides detected in other effluents of WWTPs (Kastsoyiannis and Samara, 2004; Muñoz et al., 2008)

Next, detected pesticides and their concentrations in studied effluents of each WWTP are detailed.

\subsubsection{WWTP-A}

Among all analyzed pesticides in the effluent of the WWTP-A, 3 pesticides were detected: prometon, terbuthylazine and isoproturon. Detected concentrations of these pesticides were:

- Prometon: $0.05 \mu \mathrm{g} \mathrm{L}-1$

- $\quad$ Terbuthylazine: $1.31 \mu \mathrm{g} \mathrm{L}-1$

- Isoproturon: $1.07 \mu \mathrm{g} \mathrm{L}^{-1}$

\subsubsection{WWTP-B}

Among all analyzed pesticides in the effluent of the WWTP-B, only chlorpyrifos was detected. The concentration of chlorpyrifos in this effluent was $0.074 \mu \mathrm{g} \mathrm{L}^{-1}$.

\subsubsection{WWTP-C}

Among all analyzed pesticides in the effluent of the WWTP-C, 4 pesticides were detected: chlorfenvinfos, dimethoate, terbuthylazine and simazine. Detected concentrations of these pesticides were: 
- Chlorfenvinfos: $0.024 \mu \mathrm{g} \mathrm{L}-1$

- $\quad$ Dimethoate: $0.40 \mu \mathrm{g} \mathrm{L}-1$

- $\quad$ Terbuthylazine: $1.31 \mu \mathrm{g} \mathrm{L}-1$

- $\quad$ Simazine: $0.101 \mu \mathrm{g} \mathrm{L}-1$

\subsubsection{WWTP-D}

Among all pesticides analyzed in the effluent of the WWTP-D, 4 pesticides were detected: 3,4-dichloroaniline, terbutryn, terbuthylazine and metholachlor. Detected concentrations of these pesticides were:

- 3,4-Dichloroaniline: $0.045 \mu \mathrm{g} \mathrm{L}^{-1}$

- Terbutryn: $0.077 \mu \mathrm{g} \mathrm{L}-1$

- $\quad$ Terbuthylazine: $0.89 \mu \mathrm{g} \mathrm{L}^{-1}$

- Metholachlor: $0.035 \mu \mathrm{g} \mathrm{L}^{-1}$

\subsubsection{WWTP-E}

Among all pesticides analyzed in the effluent of the WWTP-E, only dimethoate was detected. The concentration of this pesticide in this effluent was $0.272 \mu \mathrm{g} \mathrm{L}-1$. According to these results, the concentrations of detected pesticides in the 5 studied effluents are from $0.02 \mu \mathrm{g} \mathrm{L}^{-1}$ to more than $1 \mu \mathrm{g} \mathrm{L}^{-1}$. This interval of concentrations is similar to ones detected in other WWTPs by other researches (Kastsoyiannis and Samara 2004; Muñoz et al., 2008). Moreover, after this study a direct relation between detected pesticides in the effluents and treatments carried out in each WWTP hasn't been observed.

\subsection{Application in reclamation}

According to the Spanish Royal Decree 1620/2007, water must guarantee quality criteria in order to it can be reused. These criteria change in function of the use of water. Maximum admissible values of enteric nematodes, Escherichia coli, turbidity and suspended solids as well as other criteria related to other pollutants.

In accordance with the presence of hazardous substance, among them, pesticides, EQSs established in the Directive 2008/105/EC (Directive 2008/105/EC) and in the Spanish Royal Decree 60/2011 (Royal Decree 60/2011) must be respected.

This study, about the application of effluents of WWTPs in reclamation, has been carried out not taking into account microbiological parameters. Next, the possible application of studied waters in reclamation is showed. This application has been divided in two parts: on one hand, taking into account values of turbidity and suspended solids in the law; and on other hand, the presence of pesticides.

\subsubsection{Application in reclamation: turbidity and suspended solids}

As it has been mentioned previously, in the annex I of Royal Decree 1620/2007 maximum admissible values of suspended solids and turbidity are indicated in order to reuse water and depending on its use. These values are shown in the table 6. In accordance with these values and the values obtained to the effluents of studied WWTPs, some conclusions can be extracted: - WWTP-A:

According to the obtained results of suspended solids concentration and turbidity, this water cannot be applied in any use without an additional treatment. It would be needed a treatment capable to decrease, as a minimum, suspended solids in water in order to apply it in some agricultural, industrial, recreational and environmental uses. They are: 


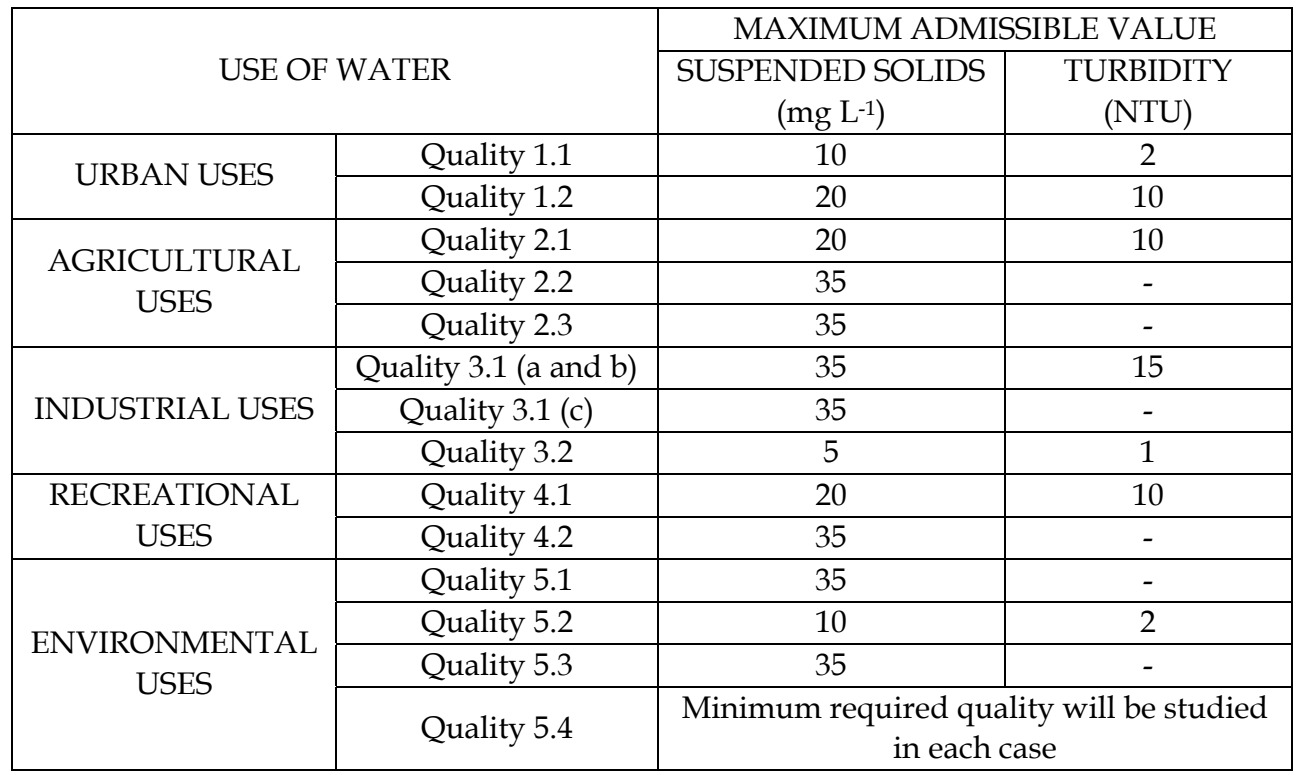

Table 6. Maximum admissible values of suspended solids and turbidity to reclaimed waters (Royal Decree 1620/2007)

- Irrigation of products to human consumption with a system of water application which doesn't avoid the direct contact between reclaimed water and comestible parts and their consumption isn't in fresh form but with an industrial treatment later.

- Irrigation of pastures to consumption of animals producing milk or meat.

- Located irrigation of woody cultivation which impedes the contact between the reclaimed water and fruits consumed in the human diet.

- Irrigation of cultivation of ornamental flowers, nurseries, greenhouses without direct contact between reclaimed water and productions.

- Irrigation of non alimentary industrial cultivation, nurseries, ensilaged forages, cereals and oleaginous seeds.

- Process and cleaning water in the alimentary industry.

- Ponds, water masses and ornamental circulated flows in which the access of people is impeded.

- Recharge of aquifers by located percolation by the ground.

- Irrigation of forests, green places and of other type which isn't accessible to people.

- Silviculture.

As well as to apply a treatment capable to reduce the suspended solids concentration in water, it would be needed to reduce the turbidity too in order to apply this water in urban uses and the rest of uses contemplated and no mentioned previously.

- WWTP-B:

According to the obtained results of suspended solids concentration and turbidity, this water can be reused without applying any additional treatment to some uses and it 
requires a posterior treatment if is destined to other uses. This water can be reused as is to some agricultural, industrial, recreational and environmental uses:

- Irrigation of products to human consumption with a system of water application which doesn't avoid the direct contact between reclaimed water and comestible parts and their consumption isn't in fresh form but with an industrial treatment later.

- Irrigation of pastures to consumption of animals producing milk or meat.

- Located irrigation of woody cultivation which impedes the contact between the reclaimed water and fruits consumed in the human diet.

- Irrigation of cultivation of ornamental flowers, nurseries, greenhouses without direct contact between reclaimed water and productions.

- Irrigation of non alimentary industrial cultivation, nurseries, ensilaged forages, cereals and oleaginous seeds.

- Process and cleaning water in the alimentary and no alimentary industry.

- Other industrial uses.

- Ponds, water masses and ornamental circulated flows in which the access of people is impeded.

- $\quad$ Recharge of aquifers by located percolation by the ground.

- Irrigation of forests, green places and of other type which isn't accessible to people.

- Silviculture.

In the case of urban uses it is necessary decrease the turbidity of water, just like to use in irrigation of golf courses and recharge of aquifers by direct injection. Its use in cooling towers and evaporative condensers is the only case in which, as well as reduce the turbidity, it is necessary decrease suspended solids in water.

- WWTP-C:

In view of characteristics of this water with regard to suspended solids and turbidity, this water could be used without applying it any additional treatment to all uses practically. Only it would be necessary an additional treatment which was capable to reduce suspended solids and turbidity of water in the case of one industrial use, in cooling towers and evaporative condensers.

- WWTP-D:

In this case, this water could be used in some sectors without applying any treatment and it would require an additional treatment in order to use in other uses. This water could be applied as is to:

- Irrigation of products to human consumption with a system of water application which doesn't avoid the direct contact between reclaimed water and comestible parts and their consumption isn't in fresh form but with an industrial treatment later.

- Irrigation of pastures to consumption of animals producing milk or meat.

- Aqueaculture.

- Located irrigation of woody cultivation which impedes the contact between the reclaimed water and fruits consumed in the human diet.

- Irrigation of cultivation of ornamental flowers, nurseries, greenhouses without direct contact between reclaimed water and productions.

- Irrigation of non alimentary industrial cultivation, nurseries, ensilaged forages, cereals and oleaginous seeds.

- $\quad$ Process and cleaning water in the alimentary industry. 
- Ponds, water masses and ornamental circulated flows in which the access of people is impeded.

- Recharge of aquifers by located percolation by the ground.

- Irrigation of forests, green places and of other type which isn't accessible to people.

- Silviculture.

In order to reuse the water to the rest of uses could be necessary to apply a treatment capable to reduce the turbidity and suspended solids up to limits established in current legislation, except to its industrial use as process and cleaning water in the alimentary and no alimentary industrial for which only a reduction of the turbidity of water would be necessary.

- WWTP-E:

With respect to the effluent of the last selected WWTP, this could be used without an additonal treatment to the most of contemplated uses: urban, agricultural, industrial, recreational and environmental. Only a subsequent treatment, capable to reduce the turbidity and suspended solids, would be necessary in order to apply this water in the next uses:

- Irrigation of private gardens.

- Emptying of health apparatus.

- Cooling towers and evaporative condensers.

- Recharge of aquifers by direct injection.

\subsubsection{Application in reclamation: pesticides}

As it has been mentioned before, as well as to obey the maximum admissible values of turbidity and suspended solids, water can be reused if it observes EQSs indicated in the Directive 2008/105/EC and in the Spanish Royal Decree 60/2011 related to hazardous substances.

Specifically regarding to pesticides, maximum admissible concentrations of some of pesticides detected in effluents of studied WWTPs are established in legislation. These values are shown as annual average (AA) and as maximum admissible concentrations (MAC). Values considered in this study are MACs in order to conclude if analyzed waters are suitable or not for reuse with respect to the presence of pesticides.

EQSs to some of detected pesticides in effluents of WWTPs are shown in the table 7.

\begin{tabular}{|c|c|c|}
\hline PESTICIDE & $\begin{array}{c}\text { EQS-AA } \\
\left(\mu \mathbf{g ~ L}^{-1}\right)\end{array}$ & $\begin{array}{c}\text { EQS-MAC } \\
\left(\mu \mathrm{g} \mathrm{L}^{-1}\right)\end{array}$ \\
\hline Chlorfenvinfos & 0.1 & 0.3 \\
\hline Chlorpyrifos & 0.03 & 0.1 \\
\hline Isoproturon & 0.3 & 1.0 \\
\hline Simazine & 1.0 & 4.0 \\
\hline Metholachlor & 1.0 & No applicable \\
\hline Terbuthylazine & 1.0 & 1.0 \\
\hline
\end{tabular}

Table 7. EQSs to some pesticides detected in WWTPs effluents (Directive 2008/105/EC, Royal Decree 60/2011)

In accordance with these values and the concentration of pesticides detected in WWTPs effluents, some conclusions can be extracted: 
- WWTP-A:

Due to the presence of pesticides this water couldn't be reused without applying an additional treatment.

Detected concentrations of terbuthylazine and isoproturon exceed the maximum admissible concentrations indicated in the current legislation, therefore it is necessary to apply a treatment capable to degrade partially these pesticides in order to reuse this water. In this water, prometon is detected too but to this pesticide, an EQS isn't indicated.

- WWTP-B:

The effluent of this WWTP could be reused without any additional treatment taking into account the presence of pesticides.

In this water, only chlorpyrifos is detected but its concentration doesn't exceed the maximum admissible one indicated in the legislation.

- WWTP-C:

In the case of this WWTP, the water couldn't be reused as is therefore an additional treatment would be necessary for this.

The addtional treatment had to reduce the concentration of terbuthylazine of the water because detected concentration of this pesticide exceedes the corresponding EQS. In this water other pesticides are detected, chlorfenvinfos, simazine and dimethoathe. However, detected concentration of chlorfenfinfos and simazine don't exceed the EQSs and for dimethote, any EQS is established.

- WWTP-D:

Regarding to the presence of pesticides, this water could be reused without treating it previously.

In this effluent, some pesticides are detected by in any case the EQSs are exceeded or there aren't EQSs indicated in the legislation to these pesticides. 3,4-dichloroaniline, terbutryn and metholaclor are detected but these pesticides aren't comtemplated in the EQSs of the legistación. Terbuthylazina is detected too, but the detected concentration doesn't exceed the maximum admissible concentration legislated.

- WWTP-E:

This effluent could be reused as is with respect to the presence of pesticides.

Only dimethoathe is detected in this WWTP effluent but this pesticide isn't considered in the EQSs in the current legislation.

\section{Conclusions}

After carrying out this study, some conclusions can be extracted.

With respect to the presence of pesticides in effluents of WWTPs:

- Usual process carried out in WWTPs doesn't get the removal of hazardous substances from water, such as pesticides.

- After carrying out the study in five WWTPs located in the Ebro river basin (Spain), detected pesticides in WWTPs effluents are: chlorfenvinfos, chlorpyrifos, dimethoate, isoproturon, prometon, metholachlor, 3,4-dichloroaniline, terbutryn, terbuthylazine and simazine.

- As well as these pesticides, other researchers have detected more pesticides in WWTPs effluents, which is shown in other research works. These pesticides are: $\alpha$-endosulphan, hexachlorociclohexanes, atrazine, diuron, hexachlorobezene, endrin, dieldrin, heptachlor, heptachlor epoxide B, $\mathrm{pp}^{\prime}$-DDD and $\mathrm{pp}^{\prime}$-DDE. 
Regarding to the characteristic of the studied WWTPs effluents:

- $\quad$ Detected concentrations of pesticides in studied WWTPs are between 0.02 and $1.31 \mu \mathrm{g}$ L-1.

- With respect to physical-chemical parameters considered in the legislation related to water reuse, turbidity and suspended solids, obtained results to studied effluents are the next: turbidity between 2 and 35 NTU and suspended solids concentration between 4 and $56 \mathrm{mg} \mathrm{L}^{-1}$.

With regard to the reuse of WWTPs effluents:

- In general, regarding to results about turbidity and suspended solids, effluents of studied WWTPs could be used without applying any additional treatment to some agricultural, industrial, recreational and environmental uses. However, in order to use the water to the rest of uses of these groups and to urban uses, an additional treatment capable to reduce turbidity and suspended solids from water would be necessary.

- In accordance with the presence of pesticides and taking into account the EQSs indicated in the current legislation, three of the five selected effluents could be reused without any additional treatment. However, in order to reuse the other two effluents, a subsequent treatment capable to degrade partially some pesticides such as terbuthylazine and isoproturon would be necessary, since detected concentrations of these pesticides exceed the established EQSs.

\section{Acknowledgements}

This work has been carried out in collaboration with "Navarra de Infraestructuras Locales S.A. (NILSA)", in the research project "Regeneración de aguas depuradas mediante procesos de oxidación avanzada (CTM2008-01876/TECNO)" financed by "Secretaría de Estado de Universidad e Investigación del Ministerio de Ciencia e Innovación”, “Diputación General de Aragón" and "Fundación Caixa Catalunya".

\section{References}

Directive 80/68/EEC of the Council of 17 December of 1979, on groundwater protection against pollution caused by dangerous substances. Diary Official of European Communities 020/L, of 26 January of 1980.

Directive 91/271/EEC of the Council of 21 May of 1991, concerning urban waste-water treatment. Diary Official of European Communities L 135, of 30 May of 1991.

Directive 2000/60/EC of the European Parliament and Council, of 23 October of 2000, by which a communitarian framework of actuation in the field of the water politics is established. Official Diary of European Communities L 327, 22 December of 2000.

Directive 2006/11/EC of the European Parliament and Council of 15 February of 2006, related to pollution caused by dangerous substances tipped in the aquatic environment of the Community. Official Diary of European Communities L 64, 4 March of 2006.

Directive 2006/118/EC of the European Parliament and Council of 23 October of 2006 relating to groundwater protection against pollution and deterioration. Diary Official of European Communities L 372, 27 December of 2006. 
Directive 2008/105/EC of the European Parliament and Council of 16 December of 2008, related to environmental quality norms in the field of the water politics. Official Diary of European Communities L 348, 24 December of 2008.

Eaton A.D., Clesceri L.S., Rice E.W., Greenberg A.E., Granson M.A.H. Standard Methods for the Examination of Water and Wasterwater. 21 Edition. APA-AWWA-WEF. ISBN 0875530478 (2005).

- Method 2540 D: "Total Suspended Solids Dried at 103/105 ${ }^{\circ}$ ".

- Method 4500-H+ B: "pH Value. Electrometric Method".

- Method 5210 B: "Biological Oxygen Demand. 5-day Test".

EPA Method 410.4. Determination of Chemical Oxygen Demand by Semi-automated Colorimetry. Revision 2.0.

EPA Method 525.2. Determination of Organic Compounds in Drinking Water by Liquidsolid Extraction and Capillary Column Gas Chromatography / Mass Spectrometry. Revision 2.0.

Hassanli A.M., Javan M., Saadat Y. Reuse of municipal effluent with drip irrigation and evaluation the effect on soil properties in a semi-arid area. Environmental Monitoring and Assessment 144, 151-158 (2008).

Hernando M.D., Malato O., Farré M., Fernández-Alba A.R., Barceló D. Environmental risk assessment of pharmaceutical residues in wastewater effluents, surface and sediments. Talanta 69, 334-342 (2006).

Imai A., Fukushima T., Matsuhige K., Kim Y.H., Choi K. Characterization of dissolved organic matter in effluents from wastewater treatment plants. Water Research 36, 856-870 (2002).

ISO Norm 7888:1985. Water quality - Determination of electrical conductivity.

ISO Norm 7027:1999. Water quality - Determination of turbidity.

Kalavrouziotis I.K., Koukoulakis P.H., Sakellariou-Makrantonaki M., Papanikolau C. Effects of treated municipal wastewater on the essential nutrient interactions in the plant of Brassica oleracea var. Italica. Desalination 242, 297-312 (2009).

Katsoyiannis A., Samara C. Persistent organic pollutants (POPs) in the sewage treatment plant of Thessaloniki, northern Greece: occurrence and removal. Water Research 38, 2685-2698 (2004).

Mendonça E., Cunha M.A., Picado A., Leitão S., Paixão S.M., Silva L., Brito F. Avaliação Directa da Toxicidade de Águas Residuais: Um Caso de Estudo. Recursos Hídricos 28 (1), 84-92 (2007).

Metclaf \& Eddy. Wastewater engineering: treatment and reuse. Mc-Graw-Hill, Inc., Nueva York (2002).

Muñoz I., Gómez M.J., Molina-Díaz A., Huijbregts M.A.J., Fernández-Alba A.R., GarcíaCalvo E. Ranking potential impacts of priority and emerging pollutants in urban wastewater through life cycle impact assessment. Chemosphere 74, 37-44 (2008).

Ormad M.P. Reutilización de aguas residuales urbanas. Gestión y tratamiento de aguas residuales. Universidad de Zaragoza y Cátedra Mariano López Navarro. ISBN 97884-938668-0-8. 155-160 (2011).

Royal Decree 1620/2007 of 7 December of 2007, about the legal regulation of the treated waters reuse. Official Bulletin of the State 294, 8 December of 2007.

Royal Decree 60/2011 of 21 January of 2011, about environmental quality norms in the sphere of the water politics. Official Bulletin of the State 19, 22 January of 2011. 
Santos J.L., Aparicio M., Callejón M., Alonso E. Occurrence of pharmaceutically active compounds during 1-year period in wastewaters from tour wastewater treatment plants in Seville (Spain). Journal of Hazardous Materials 164, 1509-1516 (2009). 


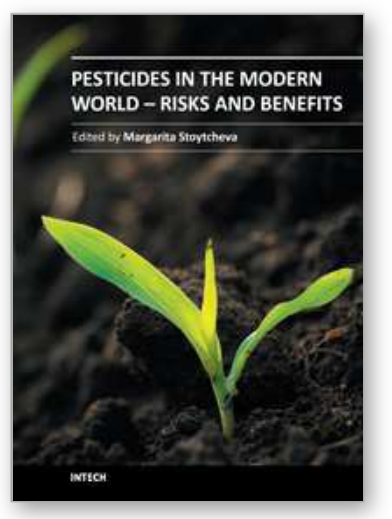

\author{
Pesticides in the Modern World - Risks and Benefits \\ Edited by Dr. Margarita Stoytcheva
}

ISBN 978-953-307-458-0

Hard cover, 560 pages

Publisher InTech

Published online 03, October, 2011

Published in print edition October, 2011

This book is a compilation of 29 chapters focused on: pesticides and food production, environmental effects of pesticides, and pesticides mobility, transport and fate. The first book section addresses the benefits of the pest control for crop protection and food supply increasing, and the associated risks of food contamination. The second book section is dedicated to the effects of pesticides on the non-target organisms and the environment such as: effects involving pollinators, effects on nutrient cycling in ecosystems, effects on soil erosion, structure and fertility, effects on water quality, and pesticides resistance development. The third book section furnishes numerous data contributing to the better understanding of the pesticides mobility, transport and fate. The addressed in this book issues should attract the public concern to support rational decisions to pesticides use.

\title{
How to reference
}

In order to correctly reference this scholarly work, feel free to copy and paste the following:

Maria P. Ormad, Natividad Miguel, Rosa Mosteo, Jorge Rodríguez and José L. Ovelleiro (2011). Study of the Presence of Pesticides in Treated Urban Wastewaters, Pesticides in the Modern World - Risks and Benefits, Dr. Margarita Stoytcheva (Ed.), ISBN: 978-953-307-458-0, InTech, Available from:

http://www.intechopen.com/books/pesticides-in-the-modern-world-risks-and-benefits/study-of-the-presence-ofpesticides-in-treated-urban-wastewaters

\section{INTECH}

open science | open minds

\author{
InTech Europe \\ University Campus STeP Ri \\ Slavka Krautzeka 83/A \\ 51000 Rijeka, Croatia \\ Phone: +385 (51) 770447 \\ Fax: +385 (51) 686166 \\ www.intechopen.com
}

\author{
InTech China \\ Unit 405, Office Block, Hotel Equatorial Shanghai \\ No.65, Yan An Road (West), Shanghai, 200040, China \\ 中国上海市延安西路65号上海国际贵都大饭店办公楼 405 单元 \\ Phone: +86-21-62489820 \\ Fax: +86-21-62489821
}


(C) 2011 The Author(s). Licensee IntechOpen. This is an open access article distributed under the terms of the Creative Commons Attribution 3.0 License, which permits unrestricted use, distribution, and reproduction in any medium, provided the original work is properly cited. 